\title{
Chemical study and anti-inflammatory activity of Capsicum chacoense and C. baccatum
}

\author{
Paula López, ${ }^{1}$ Susana Gorzalczany, ${ }^{2}$ Cristina Acevedo, ${ }^{2}$ Rosario \\ Alonso, ${ }^{I}$ Graciela Ferraro ${ }^{* 1}$
}

${ }^{1}$ Cátedra de Farmacognosia, IQUIMEFA (UBA-CONICET), Argentina; ${ }^{2}$ Cátedra de Farmacología, Facultad de Farmacia y Bioquímica, Universidad de Buenos Aires, Argentina.

\begin{abstract}
Capsicum species, Solanaceae, have been used for centuries as food additives by populations of different regions of the world. Capsaicin (trans-methyl$\mathrm{N}$-vainillyl-nonenamide) is the main pungent compound extracted from the red hot pepper fruit (Capsicum spp.). The capsaicin content was determined by means of a HPLC method. The results showed that Capsicum chacoense Hunz., contains similar amounts of capsaicin $(13.9 \mathrm{mg} / 100 \mathrm{~g}$ of dry fruit) in comparison with Capsicum baccatum L. (12.6 mg/100 g) and Capsicum annum L. (10.1 mg/100 g). Dichloromethane $\left(\mathrm{CH}_{2} \mathrm{Cl}_{2}\right)$ and ethanol $(\mathrm{EtOH})$ extracts of $C$. chacoense elicited a $46 \%$ and $38 \%$ of inhibition on the arachidonic acid (AA) pathway in ear edema respectively while the $\mathrm{CH}_{2} \mathrm{Cl}_{2}$ and EtOH extracts of $C$. baccatum inhibited $52 \%$ and $35 \%$ the arachidonic acid response respectively.
\end{abstract}

Revista Brasileira de Farmacognosia Brazilian Journal of Pharmacognosy 22(2): 455-458, Mar./Apr. 2012

\section{Short Communication}

Received 18 Mar 2011

Accepted 15 Jul 2011

Available online 14 Oct 2011

Keywords:

antiinflammatory effect capsaicin content Capsicum baccatum Capsicum chacoense

ISSN 0102-695X http://dx.doi.org/10.1590/S0102$695 \times 2011005000187$

\section{Introduction}

Capsicum, or red hot chili pepper is a popular culinary spice valued for its sensory attributes of color, pungency and flavor. There are about 23 species of chili peppers (genus Capsicum) around the world, but only 4 or 5 of them are cultivated. Due to its chemical composition, nutritional and pharmacological properties $C$. annuum has been thoroughly reviewed (Topuz \& Odzemir, 2007; Pino et al., 2007).

In Argentina there are two native Capsicum species: Capsicum chacoense Hunz and Capsicum baccatum L., Solanaceae. C. chacoense is a bush of 60 to $90 \mathrm{~cm}$ height, very ramified from the base, with alternating leaves, acuminated in their superior part, rounded in the base. The fruits are oval red 8-14 mm long berries. This specie is characteristic of areas of South America ranging from the south of Bolivia and west of Paraguay to the central region of Argentina. Its popular names are "ají del monte", "puta parió". Capsicum baccatum is a bush of a little more than half a meter, very laxly pubescent, with oval leaves, acuminated. Their fruits are red oval berries $10 \mathrm{~mm}$ long. It grows in the south of Bolivia and Brazil. In Paraguay and in the north of Argentina it is usually found in the lower grounds of the forest. Its popular name is "Ají quitucho". For centuries both species have been used locally as spicy food additives and in traditional medicine (Cabrera, 1983; Loayza, 2001).

Capsaicin (trans-methyl- $N$-vainillyl-nonena- mide) is the most pungent of the active group of compounds known as capsaicinoids that have been isolated from the genus. It is sparingly soluble in water, very soluble in fats, oils and alcohol. Other minor capsaicinoids are nordihydrocapsaicin, homocapsaicin, and homodihydrocapsaicin. Capsaicin is extracted together with its homologues from the mature fruits placentas external layers of Capsicum species. The capsaicin content depends on the botanical species, the climatic conditions and of the degree of the fruit maturity degree (Howard et al., 2000).

Capsaicin binds to the vanilloid receptor type 1 on sensory neurons to convey the pain sensation. The topical application of capsaicin has a therapeutic value in a variety of neuropathic pain conditions such as rheumatoid arthritis, diabetic neuropathy and postherpetic neuralgia (Bruneton, 2001; McCarthy \& McCarthy, 1992).

Topical creams containing $0.025-0.075 \%$ pure capsaicin, now available in the form of a prescription drug, are applied to the skin to control the pain associated with Herpes Zoster - also known as shingles-, neuralgia and postoperative amputation trauma (Brooks et al., 2002). In addition, scientists have also observed that people whose diet is high in red peppers experienced a much lower incidence of blood clotting diseases (Jaiarj et al., 1998).

Taking into account the information described, it was therefore reasonable to study $C$. chacoense capsaisin content and anti-inflammatory activity, which 
have not been previously studied and compare them with known Capsicum spp. species (Capsicum annum and $C$. baccatum).

\section{Material and Methods}

\section{Plant material}

Capsicum annum L., Solanaceae, was obtained from a cultivated commercial source. Capsicum chacoense Hunz., Solanaceae, was harvested in Tartagal, Salta and was provided and classified by R. Newmann, INTA. Salta, Argentina and C. baccatum L. was provided and classified by Prof. Dr. D. Vignale, Jujuy, Argentina. Both voucher herbarium specimens have been deposited at the herbarium of the Facultad de Farmacia y Bioquímica, Universidad de Buenos Aires, Argentina: C. chacoense Hunz. (13520 BAF) and C. baccatum L. (BAF 8694).

\section{Plant extracts}

Dried fruits $(10 \mathrm{~g})$ of each species were extracted three times with $100 \mathrm{~mL}$ of dichloromethane followed by extraction with ethanol $80^{\circ}$ using the same procedure. The $\mathrm{CH}_{2} \mathrm{Cl}_{2}$ and EtOH extracts were evaporated to dryness.

\section{Purification of extracts for HPLC analysis}

One part of each $\mathrm{CH}_{2} \mathrm{Cl}_{2}$ extract was mixed with methanol: water (70:30) and was left $24 \mathrm{~h}$ in the refrigerator. The solvent was decanted and the solid residue was separated. The methanol fraction was evaporated to dryness (Perucka \& Oleszek, 2000).

\section{HPLC method}

Preparation of the samples: $150 \mathrm{mg}$ of the purified dichloromethane extracts were dissolved in 0.2 $\mathrm{mL}$ of DMSO and were taken to volume up to $10.0 \mathrm{~mL}$ with methanol.

Standard solution: capsaicin (1.40 mg, SIGMA) was dissolved in $1.0 \mathrm{~mL}$ of DMSO and added methanol to $10.0 \mathrm{~mL}$.

The analytical column used was RP18 (5 $\mathrm{mm}, 250 \times 4.6 \mathrm{~mm}$ ). The controlled solvent gradient conditions were as follows: 0-50 min, linear gradient from $0 \%$ to $100 \% \mathrm{CH}_{3} \mathrm{CN}$ at $1 \mathrm{~mL} / \mathrm{min}$ in $0.1 \%$ aqueous trifluoroacetic acid; $50-65 \mathrm{~min}, 100 \% \mathrm{CH}_{3} \mathrm{CN}$. The injection volume was $20 \mathrm{~mL}$.

The effluent was monitored by a UV-detector $(280 \mathrm{~nm})$ and a photodiode-array detector (Sakamoto et al., 1994; Perucka \& Oleszek, 2000; Manizakiza et al., 1999).
Animals

The animals were housed in standard environmental conditions $\left(23 \pm 1{ }^{\circ} \mathrm{C}\right.$, humidity $60 \pm 5 \%$ and a $12 \mathrm{~h}$ light/dark cycle), with free access to a standard commercial diet and water ad libitum following international recommendations (Olfertet et al., 1993). Ethics approval (EXP-FYB: 0738658/2011) was from The Ethical Committee for the Care and Use of Laboratory Animals of Facultad de Farmacia y Bioquímica, Universidad de Buenos Aires

\section{Arachidonic-acid induced ear edema}

Female Swiss mice (25-30 g) were used. They were acclimatized in the laboratory for at least one week before the experience with free access to food and water. Mice were randomly assigned into groups consisting of ten animals per group. Arachidonic acid (AA) (Sigma) was dissolved in reagent-grade acetone at a concentration of $100 \mathrm{mg} / \mathrm{mL}$ and applied in a volume of $10 \mu \mathrm{L}(2 \mathrm{mg}$ AA/ear) by an automatic pipette to both the inner and the outer surfaces of the right ear.

$\mathrm{CH}_{2} \mathrm{Cl} 2$ and $\mathrm{EtOH}$ extracts of $C$. baccatum and C. chacoense dissolved in acetone were applied topically (1 mg/ear) inmmediately after the application of AA. A reference group was treated with indomethacin (2 mg/ ear).

One hour after AA treatment, mice were sacrificed and an ear punch of $6 \mathrm{~mm}$ was removed from both right and left ears. The ears were weighed and the edema induced by AA was determined by subtracting the weight of the left punch biopsies from that of the right ear. The anti-inflammatory activity was calculated and was expressed as a percentage of the edema inhibition in treated mice compared to the control mice (Carlson et al., 1985).

\section{Carrageenan-induced edema in rats}

Antiinflamatory activity was measured according to Winter et al. (1962) in female Wistar rats (170-200 g). Paw swelling was elicited by subplantar injection of 0.1 $\mathrm{mL} 1 \%$ carrageenan in $0.9 \%$ saline $(\mathrm{w} / \mathrm{v})$ in to the right hind paw.

Rats were starved for $18 \mathrm{~h}$ before the experiment with free access to water. Groups of six animals each were used. $\mathrm{CH}_{2} \mathrm{Cl}_{2}$ and EtOH extracts $(300 \mathrm{mg} / \mathrm{kg}$ ) were dissolved in ethanol:tween 80:water 5:5:90 and the reference drug indomethacin $(3 \mathrm{mg} / \mathrm{kg})$ were administered orally $1 \mathrm{~h}$ before carrageenan injection. A control group received vehicle only $(5 \mathrm{~mL} / \mathrm{kg})$. The inflammation was quantified by measuring the volume displaced by the paw, using a plethysmometer (Ugo Basile) at time 0 and $1,3,4$ and $5 \mathrm{~h}$ after carrageenan injection. The difference 
between the left and the right paw volume was determined and the percent inhibition of edema was calculated in comparison to the control animals.

\section{Results and Discussion}

The present work showed that the percentage of capsaicin of the two species of Capsicum that grow in North and Central Argentine regions (C. chacoense and $C$. baccatum) is similar to the one in $C$. annum, the most commercialized Capsicum species in the world. As capsaicin represents the main constituent of the total pungent acid amides present in the Capsicum species (Calixto et al., 2005) its content was determined by HPLC. Similar concentrations in the three species were found. $C$. chacoense showed the highest content (Table 1 ). The recovery of capsaicin was determined as $99.2 \%$, providing there was no loss of capsaicin in the purification process.

Table 1. Capsaicin content in Capsicum species.

\begin{tabular}{lcc}
\hline & $\begin{array}{c}\text { mg capsaicin/ } \mathrm{g} \mathrm{CH}_{2} \mathrm{Cl}_{2} \\
\text { extract }\end{array}$ & $\begin{array}{c}\text { mg capsaicin/100 g dry } \\
\text { fruit }\end{array}$ \\
\hline C. annum & $0.86 \pm 0.03$ & $10.1 \pm 0.3$ \\
C. chacoense & $1.10 \pm 0.05$ & $13.9 \pm 0.6$ \\
C. baccatum & $1.16 \pm 0.04$ & $12.6 \pm 0.4$ \\
\hline Results are expressed as means $\pm \mathrm{SD}(\mathrm{n}=7)$ &
\end{tabular}

Capsaicin as single oral dose moderately lowered inflammation in the carrageenan induced paw edema (Manjunatha \& Srinivasan, 2006; Reddy \& Lokesh, 1994). Moreover C. baccatum juice demonstrated an anti-inflammatory activity in a peritonitis animal model induced by carrageenan (Spiller et al., 2008). Polar and non polar extracts obtained from fruits of $C$. chacoense and $C$. baccatum were tested using two classical models of inflammation, AA-induced ear edema in mice and carrageenan induced paw edema in rats.

This study demonstrates for the first time that the $\mathrm{CH}_{2} \mathrm{Cl}_{2}$ and $\mathrm{EtOH}$ extract of $C$. chacoense $(1 \mathrm{mg} /$ ear) produced a significant inhibition of the AA-ear edema (46 and 38\% respectively) and in a similar way,
C. baccatum at the same dose induced a 52 and $35 \%$ inhibition respectively (Table 2). However, the oral administration $(300 \mathrm{mg} / \mathrm{kg})$ of all tested extracts showed no antiinflamatory activity in the carrageenan-induced paw edema (Table 3).

The vanilloid receptor 1, TRPV1, was the first mammalian member of TRPV subfamily to be identified. It is activated by vanilloid compounds such as capsaicin and resiniferatoxin. The intracellular binding domain has recently been located (Pedersen et al., 2005). Traditionally, this receptor has been considered as a pathological one, having a role in pain transduction pathway as well as pro-inflammatory effect. However, in the last years, a paradoxical protective role in certain disease state has been shown and this effect is continually expanding. Interestingly, TPRV1 are involved in the reduction of ear edema and TNF- $\alpha$ levels in an animal model of contact dermatitis (Alawi \& Keeble, 2010; Banvolgyi et al., 2005). Due to the effect was observed only by topical administration and capsaicin is one of the active compounds, it is possible that the TPRV1 receptors could be involved in the activity observed in this study. However it can't be discarded the absorption of the extract had not been enough to show systemic activity.

In conclusion, the present data shows that C. chacoense and C. baccatum could be potential substitutes for Capsicum annum in human nutrition, as phytomedicines and sources for drugs pharmaceutical development.

Table 2. Effect of Capsicum chacoense and C. baccatum extracts on AA- induced mouse ear edema.

\begin{tabular}{lcc}
\hline \multicolumn{1}{c}{ Treatment } & Edema $(\mathrm{mg})$ & Inhibition $(\%)$ \\
\hline Control & $7.36 \pm 0.44$ & ---- \\
C. chacoense $\mathrm{EtOH}$ & $4.3 \pm 0.61^{*}$ & 38.55 \\
C. chacoense $\mathrm{CH}_{2} \mathrm{Cl}_{2}$ & $3.97 \pm 0.91^{* *}$ & 46.06 \\
C. baccatum $\mathrm{EtOH}$ & $4.73 \pm 0.63^{*}$ & 35.73 \\
C. baccatum $\mathrm{CH}_{2} \mathrm{Cl}_{2}$ & $3.50 \pm 1.09 * *$ & 52.44 \\
Indomethacine & $2.62 \pm 0.39 * *$ & 64.40 \\
\hline
\end{tabular}

Results are expressed as means $\pm \mathrm{SD}(\mathrm{n}=10) . * p<0.05, * * p<0.01 \mathrm{vs}$ control. (ANOVA followed Dunnett's test).

Table 3. Effect of C. chacoense and C. baccatum extracts on carrageenan-induced paw edema in rat.

\begin{tabular}{lcccc}
\hline \multirow{2}{*}{ Treatment } & \multicolumn{4}{c}{ Edema volume $(\mathrm{mL})$} \\
\cline { 2 - 5 } & $1 \mathrm{~h}$ & $3 \mathrm{~h}$ & $4 \mathrm{~h}$ & $5 \mathrm{~h}$ \\
\hline Control & $0.21 \pm 0.03$ & $1.06 \pm 0.08$ & $1.49 \pm 0.07$ & $1.70 \pm 0.08$ \\
C. chacoense $\mathrm{CH}_{2} \mathrm{Cl}_{2}$ & $0.18 \pm 0.06$ & $1.42 \pm 0.21$ & $2.03 \pm 0.04$ & $2.05 \pm 0.10$ \\
C. chacoense $\mathrm{EtOH}$ & $0.19 \pm 0.03$ & $1.36 \pm 0.11$ & $1.86 \pm 0.16$ & $2.01 \pm 0.17$ \\
C. baccatum $\mathrm{CH}_{2} \mathrm{Cl}_{2}$ & $0.26 \pm 0.07$ & $1.51 \pm 0.15$ & $1.85 \pm 0.07$ & $1.92 \pm 0.13$ \\
C. baccatum $\mathrm{EtOH}$ & $0.20 \pm 0.05$ & $1.21 \pm 0.14$ & $1.56 \pm 0.09$ & $1.54 \pm 0.13$ \\
Indomethacine & $0.19 \pm 0.03$ & $0.43 \pm 0.07^{*}$ & $0.94 \pm 0.11^{*}$ & $1.30 \pm 0.13^{*}$ \\
\hline
\end{tabular}

Results are expressed as means $\pm \mathrm{SD}(\mathrm{n}=5)$. ${ }^{*} p<0.01$ vs control. (ANOVA followed Dunnett's test). 


\section{Acknowledgements}

This work was supported in part by grant SECYT/UBA and PICT 38219/06.

\section{References}

Alawi K, Keeble J 2010. The paradoxical role of the transient receptor potential vanilloid 1 receptor in inflammation. Pharmacol Ther 125: 181-195.

Banvolgyi A, Palinkas L, Berki R, Clark N, Grant A D, Helyes $\mathrm{Z}$ 2005. Evidence for a novel protective role of the vanilloid TRPV1 receptor in a cutaneous contact allergic dermatitis model. J Neuroimmunol 169: 86-96.

Brooks J, Pryce G, Bisogno T, Jaggar S, Hankey D, Brown P, Bridges D, Ledent C, Bifuco M, Rice A, Di Marzo V, Baker D 2002. Arvalin induced inhibition of spasticity and persistent pain. Eur J Pharmacol 439: 83-92.

Bruneton J 2001. Farmacognosia. Fitoquímica. Plantas medicinales. Zaragoza: Acribia Press.

Cabrera AL 1983. Flora de la provincia de Jujuy. Vol 13. Buenos Aires: Colección Científica Instituto Nacional de Tecnología Agropecuaria, p. 462-466.

Calixto J, Kassuya C, Andre' E, Ferreira J 2005. Contribution of natural products to the discovery of the transient receptor potential (TRP) channels family and their functions. Pharmacol Ther 106: 179-208.

Carlson RP, O'Neill-Davis L, Chang J, Lewis AJ 1985. Modulation of mouse ear edema by cyclooxygenase and lipoxygenase and inhibitors and other pharmacological agents. Agents Actions 17: 197-204.

Howard L, Talcott S, Brenes C, Villalon B 2000. Changes and phytochemical and antioxidant activity of selected Pepper cultivars (Capsicum sp.) as influence by madurity. J Agr Food Chem 48: 1713-1720.

Jaiarj P, Saichompoo S, Wongkrajang Y, Vongswan N, Peungvicha P, Jiratchariyakul W 1998. Cardiovascular actions of capsaicinoids extract from Thai Capsicum. Thai Journal of Phytopharmacy 5: 1-13.

Loayza I 2001. Capsicum y sus derivados en Ibero América. Aspectos agrícolas, cientificos, tecnológicos y económicos. La Paz: Consejo nacional de Ciencia y Tecnología.

McCarthy GM, McCarthy DJ 1992. Effect of topical capsaicin in the therapy of painful osteoarthritis of the hands. $J$ Reumatol 19: 604-607.

Manizakiza P, Covaci A, Schepens P 1999. Solid phase extraction and gas chromatography with MS determination of Capsaicin and some of its analogues from Chili Peppers (Capsicum spp). J AOAC Int 82: 1399-1405.

Manjunatha H, Srinivasan K. 2006. Protective effect of dietary curcumin and capsaicin on induced oxidation of lowdensity lipoprotein, iron-induced hepatotoxicity and carrageenan-induced inflammation in experimental rats. FEBS J 273: 4528-4537.

Olfert ED, Cross BM, McWilliam AA 1993. Guide to the care and use of experimental animals. Ottawa: Canadian Council of Animal Care.

Pedersen S F, Owsianik G, Nilius B 2005. TRP channels: an overview. Cell Calcium 38: 233-252.

Perucka I, Oleszek W 2000. Extraction and determination of capsaicinoids in fruits of hot pepper Capsicum annum L. by spectrophotometry and HPLC. Food Chem 71: 287-291.

Pino J, González M, Ceballos L, Centurión-Yah, AR, TrujilloAguirre J, Latournerie-Moreno L, Sauri-Duch E 2007. Characterization of total capsaicinoids, colour and volatile compounds of Habanero chilli pepper (Capsicum chinenese Jack.) cultivars grown in Yucatan. Food Chem 104: 1682-1686.

Reddy ACP, Lokesh BR 1994. Studies on anti-inflammatory activity of spice principles and dietary n-3 polyunsaturated fatty acids on carrageenan- induced inflammation in rats. Ann Nutr Metab 38: 349-358

Sakamoto S, Goda Y. Maitani T, Yamada T, Nunomura O, Ishikawa K 1994. High-performance liquid chromatographic analyses of capsaicinoids and their phenolic intermediates in Capsicum annum to characterize their biosynthetic status. Biosci Biotechnol Biochem 58: 1141-1142.

Spiller F, Alves M, Vieira S, Carvalho T, Leite C, Lunardelli A, Poloni J, Cunha F, de Oliveira J 2008. Antiinflamatory effects of red pepper (Capsicum baccatum) on carrageenan-and-antigen-induced inflammation. $J$ Pharm Pharmacol 60: 473-478.

Topuz A, Odzemir F 2007. Assessment of carotenoids, capsaicinoids and ascorbic acid composition of some selected pepper cultivars (Capsicum annum L.) grown in Turkey. J Food Compos Anal 20: 596-602.

Winter CA, Risley EA, Nuss GW 1962. Carrageenaninduced edema in hind paw of the rat as an assay for antiinflammatory drugs. Proceedings of Society of Experimental Biological Medicine 111: 554-547.

\section{*Correspondence}

Graciela Ferraro

Cátedra de Farmacognosia, IQUIMEFA (UBA-CONICET)

Junín 956 (1113), Buenos Aires, Argentina

gferraro@ffyb.uba.ar

Tel: +54 $1149648247 / 8$

Fax: +541145083642 